\title{
A new species of the interstitial genus Neopetitia (Polychaeta, Syllidae, Eusyllinae) from Tenerife, with modified acicular chaetae in males
}

\author{
Rodrigo Riera $\cdot$ Jorge Núñez $\cdot$ María del Carmen Brito
}

Received: 4 January 2007 / Revised: 10 April 2007 / Accepted: 12 April 2007 / Published online: 22 May 2007

(C) Springer-Verlag and AWI 2007

\begin{abstract}
A new species of Neopetitia San Martín, 2003 is described from intertidal and shallow subtidal soft-bottom stations on the eastern and western coast of Tenerife, Canary Islands. The new species is characterized by the presence in males of a modified acicular chaeta in chaetiger 11. A discussion of known species of the genus is presented.
\end{abstract}

Keywords Syllidae $\cdot$ Eusyllinae $\cdot$ Neopetitia .

Soft-bottoms $\cdot$ Tenerife $\cdot$ Canary Islands

\section{Introduction}

The genus Neopetitia San Martín, 2003 is strictly interstitial, and has been collected exclusively in exposed intertidal sandy beaches (Siewing 1956). This genus comprises so far two species: $N$. amphophthalma (Siewing, 1956) and $N$. occulta (Westheide and Hass-Cordes, 2001). The first species is considered to have a worldwide distribution and the second one has been collected at the Seychelles archipelago. The two species present a similar appearance and can be differentiated only by molecular analysis (Westheide and Hass-Cordes 2001).

During ecological studies of the sandy beach of Los Abrigos on the eastern coast of Tenerife and the marine cave "Los Cerebros" on the western coast of Tenerife

Communicated by H.-D. Franke.

R. Riera $(\varangle) \cdot$ J. Núñez $\cdot$ M. del Carmen Brito Benthos Laboratory, Department of Animal Biology, Faculty of Biology, University of La Laguna, 38206 La Laguna, Tenerife, Canary Islands, Spain e-mail: rodrigo@cimacanarias.com
(Fig. 1), several specimens of Neopetitia were collected. A detailed study of these specimens revealed that male organs comprise a stout copulatory chaeta in chaetiger 11 , a character not observed before in this genus. Furthermore, chaetiger 11 is modified by the absence of long-bladed dorsal chaetae. This character also had not been observed before in this genus, neither in specimens collected in El Pris and El Médano, two localities of Tenerife, identified as N. amphophthalma (von Soosten et al. 1998) (Westheide, personal comunication).

\section{Materials and methods}

Quantitative samples from Los Abrigos beach were collected at $0-3 \mathrm{~m}$ depth by means of PVC cores to a sediment depth of $30 \mathrm{~cm}\left(475 \mathrm{~cm}^{3}\right)$. Each month, five replicates were collected for faunistic analysis and one for the analysis of abiotic factors (granulometry, organic matter, carbonates and nitrogen). Semiquantitative $\left(250 \mathrm{~cm}^{3}\right)$ samples from Los Cerebros volcanic cave were collected at $12 \mathrm{~m}$ depth on sandy patches. Samples were fixed and preserved in $4 \%$ neutralized formalin-seawater solution. Thereafter, samples were sieved on a $63-\mu \mathrm{m}$ mesh and then transferred to $70 \%$ ethanol. Several whole specimens were mounted in glycerine jelly; examination was made by means of a compound microscope provided with DIC optics (Nomarski). Drawings were made to scale with a camera lucida drawing tube, and photographs were taken by a camera fitted to the microscope.

The type material is deposited in the collections of the Natural Sciences Museum of Santa Cruz de Tenerife (TFMC), and at the Department of Animal Biology (Zoology) of the University of La Laguna (DZULL), Canary Islands. 


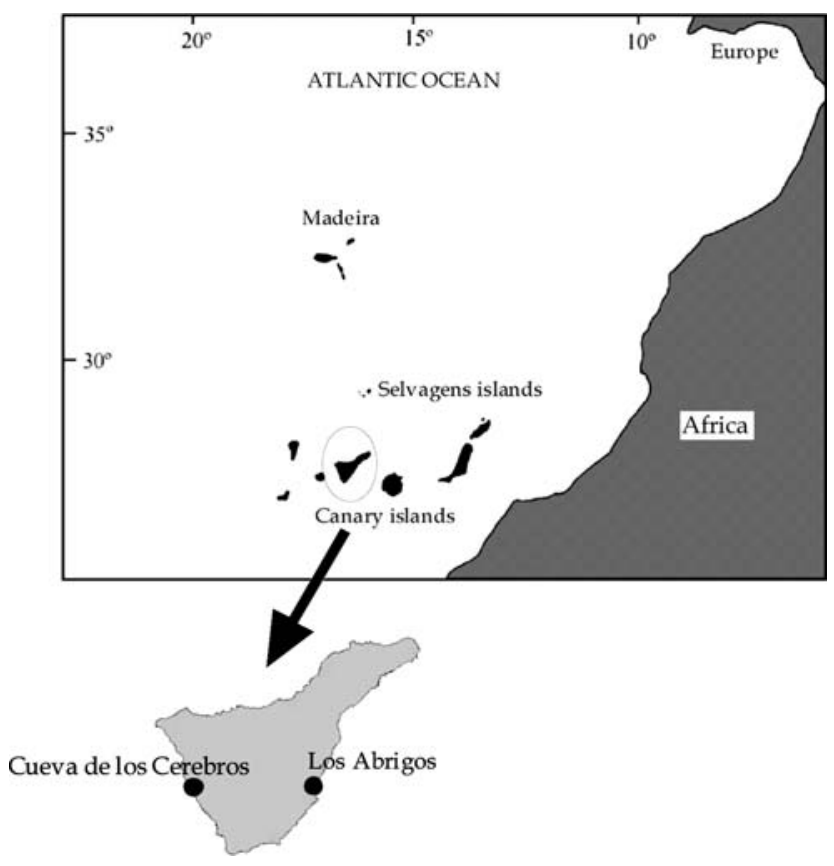

Fig. 1 Map of study sites

\section{Results and discussion}

Polychaeta Grube, 1850

Syllidae Grube, 1850

Eusyllinae Malaquin, 1893

Neopetitia San Martín, 2003

Neopetitia abadensis, n. sp. (Fig. 2, 3).

Type locality: Tenerife, Playa de Los Abrigos, coordinates $28^{\circ} 08^{\prime} 34^{\prime \prime} \mathrm{N} / 16^{\circ} 26^{\prime} 21^{\prime \prime} \mathrm{W}$; intertidal, medium sand; February 2001; col. R. Riera.

Type material: Holotype, whole-mounted in glycerine jelly TFMC-AN/00014. Paratypes: 2 specimens wholemounted in glycerine jelly TFMC AN/00015, 00016.

Additional material: Tenerife, Cueva de Los Cerebros, coordinates $28^{\circ} 10^{\prime} 21^{\prime \prime} \mathrm{N} / 16^{\circ} 4827^{\prime \prime} \mathrm{W} ; 7-12 \mathrm{~m}$ depth, June 2004; DZULL-PO-M4, 3 specimens, col. J. Núñez and Ó. Monterroso.

Description: Body slender and short, colourless, tapering towards both ends (Fig. 2a, b). Holotype about $0.8 \mathrm{~mm}$ long, not including palps and anal cirri; $0.1 \mathrm{~mm}$ wide at level of proventriculus without parapodia, with 16 chaetigers.

Prostomium oval, slightly wider than long; two eyes situated in the posterior half of the prostomium, sometimes inconspicuous. Three smooth and filiform antennae; median antenna longer $(170 \mu \mathrm{m})$ than lateral ones $(130 \mu \mathrm{m})$. Two biarticulated palps, with a spherical palpostyle slightly acuminated distally. Palpophores wider and slightly longer than palpostyles. Two tentacular cirri nar-

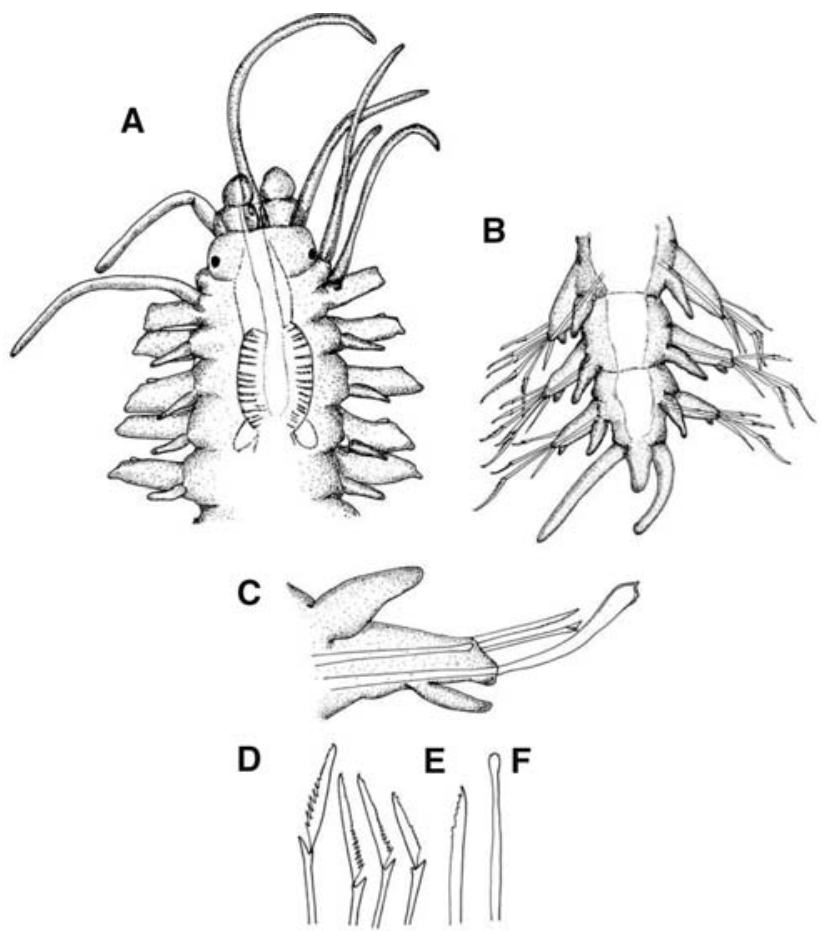

Fig. 2 Neopetitia abadensis sp. nov. a anterior end, dorsal view; b posterior end, dorsal view; c chaetiger 11 with modified acicular chaeta; d compound chaetae; e dorsal simple chaeta; f acicula. Scale: a, $\mathbf{b}=80 \mu \mathrm{m} ; \mathbf{c}-\mathbf{f}=40 \mu \mathrm{m}$

rower than the remaining cirri and similar to antennae in length, being dorsal $(111 \mu \mathrm{m})$ longer than ventral $(84 \mu \mathrm{m})$ (Fig. 2a).

Pharynx narrow, extending through about three segments, provided with a conspicuous tooth on the anterior end (Fig. 3c). Proventriculus shorter than pharynx, extending through about two segments. Dorsal cirri of the first chaetiger similar in length $(132 \mu \mathrm{m})$ to antennae and tentacular cirri. Dorsal cirri on the second chaetiger and backwards shorter and digitiform. Ventral cirri digitiform, arising distally of the parapodial lobe. Each chaetiger with one simple dorsal chaeta, 3-6 compound falciger chaetae with blades decreasing slightly in size from dorsalmost to ventralmost (Fig. 2d), and a solitary acicula with knobbed tip (Fig. 2f). Dorsal simple chaetae bidentate and distinctly serrated in the distal end (Fig. 2e). Compound falciger chaetae with long and bidentate blade, subdistally spinulated in the concave side. Pigidium with one median anal appendage and one pair of lateral cirri, about two-times longer than the median appendage (Fig. 2b).

Chaetiger 11 of males strongly modified in chaetal composition (Fig. 2c, 3d), with only a single, poorly developed $(4 \mu \mathrm{m})$ compound falciger chaeta (Fig. 3f). Dorsal simple chaeta and acicula not modified. One ventral acicular chaeta subdistally expanded and piriform in the distal end (Fig. 3e). Dorsal and ventral cirri of chaetiger 11 not modified. 
Fig. 3 Neopetitia abadensis sp. nov. a entire body; $\mathbf{b}$ anterior end; $\mathbf{c}$ pharynx with tooth; $\mathbf{d}$ chaetiger 11 with modified acicular chaetae; e acicular chaeta, ventral view; $\mathbf{f}$ acicular chaeta and compound chaeta of chaetiger 11. Scale: $\mathbf{a}=150 \mu \mathrm{m}$; $\mathbf{b}=75 \mu \mathrm{m} ; \mathbf{c}=30 \mu \mathrm{m}$; $\mathbf{d}=35 \mu \mathrm{m} ; \mathbf{e}=25 \mu \mathrm{m}$; $\mathbf{f}=30 \mu \mathrm{m}$
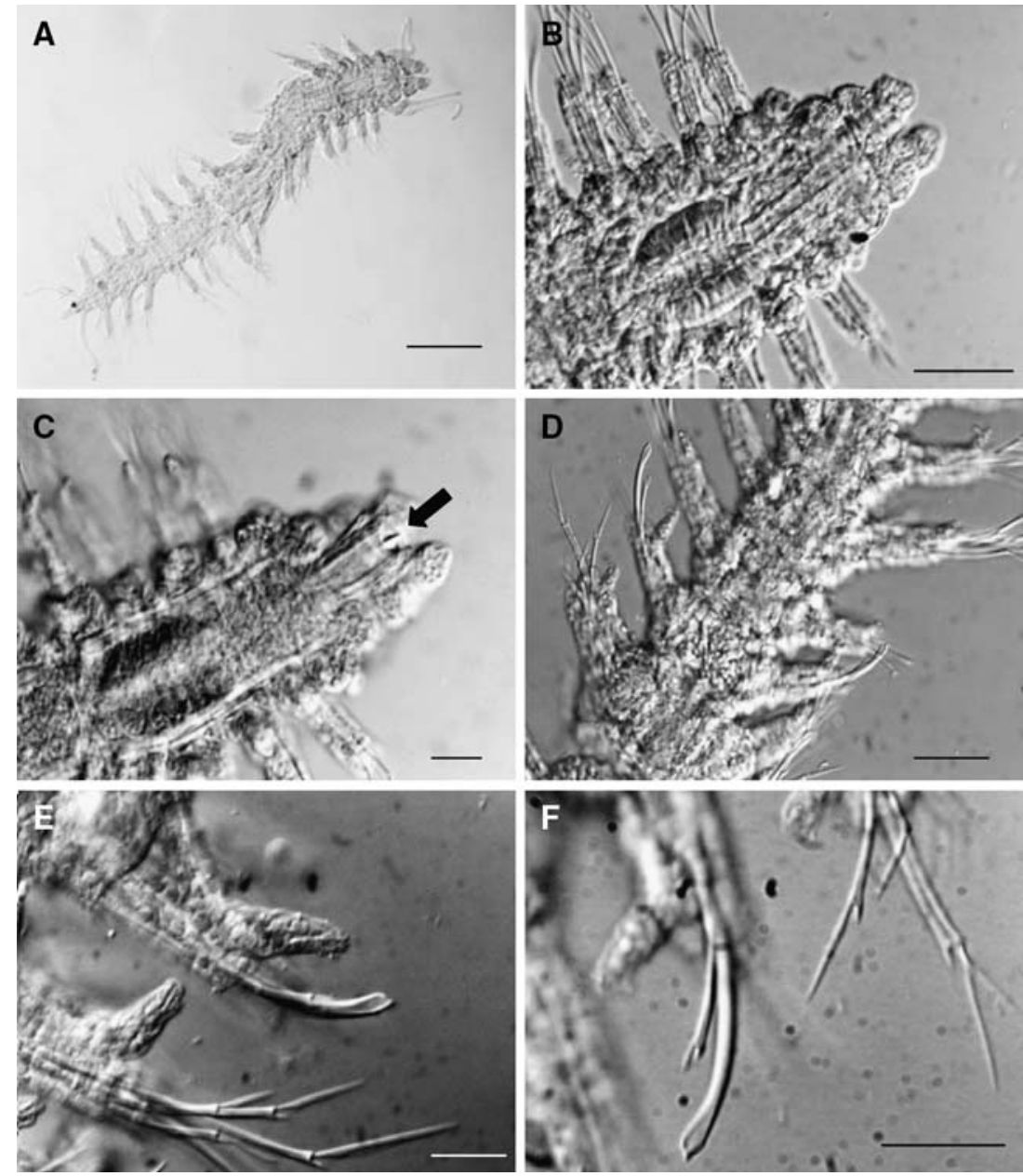

Discussion: Two species of the genus Neopetitia have been previously described, $N$. amphophthalma (Siewing, 1956) and N. occulta (Westheide and Hass-Cordes, 2001). The last one has been described from the Seychelles Archipelago (Indian Ocean), and is characterized by eight DNA fragments, which do not exist in specimens of N. amphophthalma (Westheide and Hass-Cordes 2001). N. amphophthalma is considered to be a cosmopolitan species (Ding and Westheide 1997). The new species $N$. abadensis can be separated from the other two species by the presence of a modified chaetiger 11 in males, being characterized by the presence of a modified acicular chaeta.

Ecology: In Los Abrigos beach this species was found in intertidal well-selected medium sands $\left(Q_{50}=0.42\right.$, $S_{0}=1.04$ ), with $1.62 \%$ of organic matter content and $5.64 \%$ of carbonate percentage. In the shallow-subtidal, this species was collected in medium well-selected sands $\left(Q_{50}=0.36, S_{0}=0.86\right)$, with $1.68 \%$ of organic matter and $3.08 \%$ of carbonates percentage.

Etymology: The species name refers to Los Abades, a locality near to the type locality.
Acknowledgments We thank Aguirrre Servicios Topográficos S.L.L., in special H. Aguirre and Ó. Monterroso, for prodiving environmental data of the marine cave "Los Cerebros". We acknowledge W. Westheide for his insightful comments and encouragement.

\section{References}

Ding D, Westheide W (1997) New records and descriptions of tidal and subtidal syllid species (Polychaeta) from the Chinese coast. Bull Mar Sci 277-292

San Martín G (2003) Annelida, Polychaeta II: syllidae. En Fauna Ibérica, vol 21. In: Ramos MA, Alba J, Bellés X, Gosálbez J, Guerra A, McPherson E, Serrano J, Templado J (eds) Museo Nacional de Ciencias Naturales, CSIC, Madrid

Siewing R (1956) Petitia amphophthalma n. gen. n. sp., ein neuer Polychaet aus dem Sandlückensystem. Vie Milieu 6:413-425

Soosten C von, Schmidt H, Westheide W (1998) Genetic variability and relationships among geographically widely separated populations of Petitia amphophthalma (Polychaeta: Syllidae). Results from RAPD-PCR investigations. Mar Biol 131:659-669

Westheide W, Hass-Cordes E (2001) Molecular taxonomy: description of a cryptic Petitia species (Polychaeta: Syllidae) from the island of Mahé (Seychelles, Indian Ocean) using RAPD markers and ITS2 sequences. J Zool Syst Evol Res 39:103-111 